\title{
The Determinants of Postsecondary Enrolment Rates in Ontario
}

\author{
DAVID K. FOOT and BARRY PERVIN*
}

\begin{abstract}
This paper examines the determinants of postsecondary enrolment rates in Ontario in the context of economic theories of educational demand. The traditional consumption and investment theories are found to provide significant determinants of observed enrolment rates, especially for universities. Community college enrolments appear to be more income sensitive than university enrolments and, within the university student body, graduate enrolments appear to be more price sensitive than undergraduate enrolments. In addition, an indicator of cohort size is shown to have a depressing effect on enrolment rates. No significant effects of "competition" between universities and community colleges are discerned. The results are used to account for the stabilization in postsecondary enrolment rates in Ontario over the 1970s and to provide insights into likely future developments. Illustrative calculations suggest that, on average, enrolment rates in postsecondary institutions are likely to increase over the 1980s, primarily as a result of increasing per capita incomes and declining cohort sizes. Consequently, the often anticipated decline in postsecondary enrolments is unlikely to materialize and public policies towards postsecondary institutions, especially universities, must be careful to incorporate this information.
\end{abstract}

\section{RÉSUMÉ}

Cet article analyse les facteurs déterminants des taux d'inscription au postsecondaire en Ontario dans le contexte des principes financiers de la demande en matière d'éducation. Les théories traditionnelles de consommation et d'investissement s'avèrent être des facteurs significatifs des taux d'inscription étudiés, principalement pour les universités. Les taux d'inscription dans les collèges communautaires semblent dépendre davantage du revenu que les inscriptions à l'université. $A u$ sein de la population étudiante universitaire, les inscriptions aux grades

* David K. Foot is Associate Professor of Economics, University of Toronto. Barry Pervin is Assessment Officer with the Planning. and Development Branch, Skills Development Division, Ontario Ministry of Colleges and Universities.

The opinions expressed in this paper are those of the authors. 
supérieurs paraissent dépendre plus des coûts qu'au premier cycle. De plus, il est démontré que la surpopulation a un effet dépressif sur les taux d'inscription. Aucune compétition entre collèges et universités n'a été notée. Les résultats sont utilisés pour expliquer une stabilisation des inscriptions au post-secondaire en Ontario dans les années 70, et pour fournir un aperçu des développements probables. Les calculs démontrent qu'en moyenne, les inscriptions dans les institutions postsecondaires augmenteront dans les années 80 , en raison principalement de l.augmentation des revenus per capita et du déclin démographique. Par conséquent, il est peu probable que les fréquentes prévisions de diminution des inscriptions au niveau postsecondaire se réalisent. Les politiques gouvernementales envers les institutions postsecondaires, particulièrement les universités, doivent donc tenir compte de cette information.

\section{INTRODUCTION}

There appears to be a widespread belief, both in the educational institutions and in the literature, including the press, that over the next decade or two substantial declines in postsecondary enrolments will be experienced by institutions of higher learning in Canada and in Ontario. This view, which is supported by several recent empirical studies (see, for example, Clark, Devereaux and Zsigmond, 1979 and Statistics Canada, 1979), is based mainly on demographic considerations: namely, the prospective decline in the cohort size of university and college-aged persons. Although the exact magnitude of this decline remains in debate, the Science Council of Canada (1979) estimated that full-time university enrolment in Canada will decrease by about 20 percent between 1982 and 1994 in line with a similar decrease in the size of the 18 to 24 year age group. In addition, a study by Keyfitz (1978) of college enrolments in the United States came to similar conclusions, postulating a drop of 10 percent in total enrolment by 1985 and a further drop of 20 percent by the early 1990s.

The implications of these demographically-based conclusions are striking. First, they raise concerns that postsecondary institutions may face a troubled future in terms of their financial viability, since declining student numbers will result in reduced tuition income and policy makers may be tempted to cut back support to postsecondary education in anticipation of demographically-induced declines in enrolment. Second, as financial support through tuition and operating grants tapers off, there are fears that this may lead to the closing of some institutions and result in layoffs of university and college teachers. Third, these considerations could result in a decline in research at the university level at a time when Canada consistently ranks below other OECD countries in terms of the percentage of GNP devoted to research and development. Fourth, it also raises fears of future labour shortages in specific occupations as the output of postsecondary trained persons fails to match the anticipated demand by employers.

However, as has been pointed out elsewhere (see, for example, Foot, 1981 and Ahlburg, Crimmins and Easterlin, 1981), actual student enrolments are determined 
not only by cohort size but also by the enrolment rate (the percentage of a particular age cohort which chooses to attend a postsecondary institution), which is affected by numerous factors other than simply demographic considerations (see Handa and Skolnick, 1975). Such factors as students' perceptions of the returns from a postsecondary education in terms of increased income and employment opportunities may be important considerations in determining whether or not to seek a postsecondary education. The possibility that enrolment rate changes for the university and college age groups might compensate for the adverse changes in their numbers remains largely unexplored in the literature. By way of an example, a study conducted by Ahlburg, Crimmins and Easterlin (1981) found that college enrolment rates in the United States were expected to increase between 1977 and 2000 and more than compensate for the projected adverse changes in the college age population over the period.

To explore this issue in Canada, it is first necessary to understand the determinants of postsecondary enrolment rates. The primary purpose of this paper is to empirically explore the factors which have influenced postsecondary fulltime enrolment rates in Ontario over the 1960 s and $1970 \mathrm{~s}$ in the context of economic theories of educational demand. The usefulness of economic theories of educational demand in providing a theoretical focus for such analyses is well established (see, for example, Becker, 1964). An understanding of the factors which influenced enrolment rates in the past can contribute to an understanding of how enrolment rates may behave in the future and hence guide public policy. The approach developed in this paper can be used as a basis for projecting future enrolment rates which, when combined with demographic projections of university and college-aged persons, enables the expected number of students enroled in postsecondary institutions to be projected (see, for example, Ahlburg, Crimmins and Easterlin, 1981 for the U.S. and Foot, 1981 for Canada). This exercise also is briefly explored in this paper.

The next section of the paper briefly reviews three alternative economic theories of educational demand that have appeared in the literature and develops a framework for analysing their roles in the context of the current problem. This is then followed by an outline of the data used to test the theories, the results of which are presented and discussed in the subsequent section. The following Section explores some implications of the results and the paper concludes with a summary of the main findings.

\section{ECONOMIC THEORIES OF EDUCATIONAL DEMAND}

Empirical analyses of educational demand make sense only if they relate to a theory or theories of educational demand. Three established theories of the demand for education are reviewed here: the consumption theory, the investment theory and the cohort size theory. The consumption approach views enrolment as a current consumption decision; the investment approach views enrolment as an investment decision and the cohort size approach suggests that demographic conditions are paramount in decisions concerning postsecondary educational demand. 


\section{The Consumption Theory}

The consumption theory of educational demand is based on the conventional economic theory of consumer behavior, which treats education as a normal consumer good and suggests that its demand is primarily a function of its relative price and the income of the consumer. The underlying notion of the consumption model is that all normal goods, including education, are consumed because they yield satisfaction (or utility). An increase in the consumer's income, all other things being unchanged, enables the consumer to consume more of education and of all other commodities. As a result, consumer demand theory would predict that an increase in income would have a positive effect on the quantity of education consumed or, in other words, on enrolment in postsecondary institutions. Similarly, a decrease in income would have the opposite effect. The effect of an increase in the price of education, all other things remaining unchanged, is that education becomes relatively more expensive and the consumer switches demand away from education and towards other commodities. In addition, the increase in price reduces the purchasing power of the consumer's income thereby enabling less of education and of all other commodities to be purchased. Hence, an increase in the price of education would have a negative impact on the consumption of education or on enrolment in postsecondary institutions. Similarly, a fall in the relative price of education will have the opposite effect.

Both the price and income variables have received considerable discussion in the literature on educational demand. Campbell and Siegel (1967), in a study of postsecondary enrolment demand in the United States over the period of 1919. 1964 , found that these two variables explained 87 percent of the variation in the demand for education. The income variable had an elasticity of 1.20 while the price variable (for tuition) had an elasticity of -0.44 , both of which had a high degree of statistical significance. Handa (1972), came to similar conclusions for Canada although the price and income elasticities were larger (with price elasticities of -1.46 and -6.38 and income elasticities of 6.0 and 14.0 for undergraduate and graduate enrolment, respectively). These and other studies have shown that these two variables have a significant effect on postsecondary enrolment propensity.

\section{The Investment Theory}

Unlike the consumption theory the investment theory views education as an investment decision, which suggests that individuals will "purchase" a university education if the expected benefits of such an "investment" exceeds the costs of acquiring the education, where both are appropriately discounted to yield a present value. The expected stream of benefits has two elements: 1) the possible additional lifetime money income resulting from higher education, and 2) the additional psychic benefits a person might expect to receive as a result of having obtained a postsecondary education. The costs include: 1) the direct costs of acquiring the education such as tuition and fees, books, living costs and other outlays, 2) the opportunity costs of foregone income incurred while in school 
and 3) the non-monetary costs associated with an adjustment to a new way of life, etc. The investment model assumes that an individual assigns an implied rate of return in considering the expected benefits of an educational investment. Thus, the investment model would suggest that an individual facing an enrolment decision presumably makes the decision in the light of the net present value of the expected benefits and costs associated with the decision, with a positive net present value resulting in a decision to enrol in a postsecondary institution.

The following propositions emerge from the investment theory: 1) a general increase in income or the perception of higher income after graduation, would increase the demand for education since it increases the benefits and hence the net present value of acquiring a postsecondary education; 2) an increase in the cost of education, such as direct money costs or increased opportunity costs, would lead to a reduction in enrolment demand since it decreases the net present value of acquiring an educational investment; and 3) a general increase in unemployment would likely lead to an increase in the demand for education since it reduces the opportunity costs and hence increases the net present value of a postsecondary education. Similarly, decreases in income, costs, or unemployment would have the opposite effects.

This human capital framework has received considerable attention in the literature on educational demand (see, for example, Becker, 1964 and Mincer, 1974). A recent empirical confirmation can be found in the work of Pissarides (1982) who examined the demand for post-compulsory education in Britain over the period 1955 to 1978 . In this study the critical variable determining the demand for education was the present value of earnings of people with different educational qualifications, and the decline in the rate of return to higher education was identified as one of the main factors responsible for the depression in student numbers over the 1970s.

Handa and Skolnick (1975), in a study of university enrolment in Ontario between 1950 and 1965, found that undergraduate enrolment was positively associated with youth unemployment. The authors posited that increases in the number of young unemployed reduced the opportunity costs of attending a postsecondary. institution, which increased the net present value of the educational investment. In essence, students were encouraged to remain in school to increase their skill level and marketability rather than face a hostile employment market. While the elasticity of undergraduate enrolment demand with respect to youth unemployment was not high at 0.15 , the inclusion of the unemployment variable increased the $\mathrm{R}^{2}$ from 0.95 to 0.97 and improved the DW statistic substantially. The authors found no significant relationship between unemployment and graduate enrolment.

In a previous article, Handa and Skolnick (1972) discussed some of the theoretical concerns relating to the choice of the opportunity cost variable. An opportunity cost variable, however it was to be defined, had essentially two possible components: 1) the expected level of foregone earnings while at school, and 2) expectations concerning the probability of employment upon graduation. 
The first component represented opportunity costs in terms of foregone income while the second represented the costs associated with unemployment. In judging which of these two variables was the more appropriate, the authors found that the statistical problems associated with the impact of unemployment are less than those associated with opportunity wages. In the case of the latter, because students may use part-time or summer earnings to finance their studies, it is difficult to separate the effects of this variable as a "source of finance" from its effect as reflecting opportunity wage loss. The authors pointed out that the study by Campbell and Siegel (1967) omitted opportunity wage loss precisely for this reason. The opportunity wage variable may also be highly correlated with family income and might obscure the effect of the income variable. More specifically, it can also be argued, that in periods of high unemployment when wages are relatively inflexible, the expected probability of employment may be a more significant factor in student enrolment decisions than the opportunity wage loss. This was suggested in an analysis of secondary school retention rates by Crean (1971), where it was found that marginal changes in unemployment rather than wages were more likely to influence student enrolment decisions. Because of these reasons, the unemployment rate rather than wages has often been used as the opportunity cost variable in empirical studies.

\section{The Cohort Size Theory}

Work by Easterlin (see, for example, Easterlin, 1980) and his collaborators suggests that the increase in the relative size of young adult cohorts since World War II, echoing the fertility swings since the 1930s, has had a pervasive effect on the social and economic conditions in society. Easterlin argues that the comparative size of one's generation is crucial in determining one's life chances and hence one's decisions, including the decision to obtain a postsecondary education.

Easterlin develops three propositions in explaining his theory. First, he links the decision to marry and to have children to the family's perceived likelihood of achieving their economic aspirations. The more a couple feels that their economic aspirations will be met the more likely they will marry and have children. Second, he suggests that the likelihood of achieving their economic aspirations is influenced by the relative supply of younger to older workers when in their early working ages. If younger workers are in relative short supply, their earnings, employment experience and career advancement will be favourably affected. This in turn will positively influence their perceived economic security and, in turn, their willingness to have children. Third, the supply of younger workers relative to older workers depends on their generation size, which is determined in part by the birth rate approximately 20 years earlier.

Easterlin argues that persons born in the low birth rate period of the 1930s found that they were in short supply when they reached working age 20 years later in the 1950s. In turn, they found relatively high wages, rapid career advancement and a highly favourable economic environment. As a result, couples felt 
secure that their economic aspirations would be met and many decided to have children. Easterlin argues that this led to the high birth rate period of the $1950 \mathrm{~s}$ known as the post-war baby-boom period. As the cycle continued, persons born in the high birth rate period of the 1950s, found that they were in excess supply when they reached working age 20 years later in the 1970s. In turn, they found stiff competition for jobs, slow advancement, relatively low wages and a less favourable economic environment. Consequently, couples felt less secure about their economic future and many decided either not to have children, or to decrease the number of children they did have. This resulted in what is now sometimes referred to as the baby-bust. Hence small generations tend to produce large ones which in turn produce small ones, etc. Easterlin concludes that these cycles repeat themselves making it possible to predict future conditions in society.

With regard to the impact of Easterlin's theory on the demand for postsecondary education, Freeman $(1975,1977)$ found that the size of the post-war baby-boom depressed the returns to a college education in the United States (between 1969 and 1974), which reduced the attractiveness of seeking a postsecondary education, reduced the net present value of an educational investment and accounted for the drop in enrolment observed in the late 1970s. Freeman found the rate of increase in the salaries of the college trained declined relative to other workers. Real college salaries fell by as much as 5.1 per cent in some disciplines over this period compared to a slight increase in relative wages for other workers. In addition, Freeman also found that real starting salaries for college graduates were well below those five years earlier, and relative earnings to those of other workers were 13 to 27 per cent below 1969 levels. Freeman suggests that these declines in relative wages were a consequence of the oversupply of college graduates, which was a reflection of cohort size.

The relative decline in earnings was also accompanied by a decline in the rate of growth in "college-level" jobs, which includes professional and managerial occupations. This was particularly true for men. In addition, declines in the relative shares of such jobs in total employment after 1969 were also found.

Freeman concludes that as a result of the relative decline in the income of college graduates compared to other workers and the continuing increase in the direct cost of a college education, private (and social) returns to investing in postsecondary education fell sharply over this period. This is directly attributable to an increase in the cohort size of those of college and university age which reduces the returns to a postsecondary education and, consequently, has a negative effect on postsecondary enrolments.

A more direct examination of the impact of cohort size on the demand for higher education can be found in the study of Ahlburg, Crimmins and Easterlin (1981), who introduce a smoothed, lagged, average general fertility rate into their equations. It is found to have the expected significant negative impact on college enrolment rates especially for younger males and females. In this context it is also noted that there is a second effect of cohort size on college enrolments. Termed the sibling effect, it argues that as members of the baby-boom cohort 
reached college age they were more likely then the previous cohort to have a sibling who was also of college age since increases in the fertility rate imply increasing numbers of children per family and/or declining child-spacing spans. With parental income constant, the increased pressure on family resources of another college enrolment, decreased the probability of any given individual's enrolment in college. Consequently, this impact of cohort size further reduces the demand for postsecondary education.

\section{Review of the Three Theories}

The three theories outlined above provide complementary rather than competing explanations of the demand for postsecondary education. Each suggests a set of influences which may be relevant in any comprehensive explanation of the movements in postsecondary enrolments. In some cases, such as income and price (the direct costs of education), the explanatory factor is suggested by more than one theory while in other cases, such as unemployment and cohort size, the factor is theory-specific.

Moreover, there are a number of clear linkages between the theories. The cohort size theory, for example, provides a justification for the stream of benefits which is the basis for the investment theory. The increased cohort size resulting in an oversupply of college graduates tends to reduce the returns to a postsecondary education and the net present value of an educational investment which in turn reduces postsecondary enrolment rates. The consumption theory and, to a lesser extent the sibling effect of the cohort size theory, view income as a source of financing higher education, whereas in the investment theory it represents the returns to a higher education. In all cases, however, increased incomes are postulated to increase educational demand. Similarly, increased tuition fees represent increased prices in the consumption theory and increased direct costs in the investment theory, both of which result in downward pressures on educational demand. However, not all factors work in the same direction. Increases in unemployment rates, while decreasing the opportunity costs and hence increasing the demand for education, may also decrease family incomes and hence lower the demand for education.

In essence, these theories individually provide only a partial explanation of the demand for postsecondary education. However, when taken together, as they are in this paper, they may provide a comprehensive explanation of the economic factors affecting postsecondary enrolment demand.

This comprehensive view may be summarized by the following general relationship between the enrolment rate (denoted ENR) and the key explanatory variables outlines by the above theories: ${ }^{1}$

$$
\mathrm{ENR}=\beta_{0}+\beta_{1} \text { INCOME }+\beta_{2} \text { PRICE }+\beta_{3} \text { OPCOST }+\beta_{4} \text { COHORT }
$$

where, based on the above theories, the parameters $\left(\beta^{\prime} s\right)$ are expected to assume the following signs: 


$$
\beta_{1}>0, \beta_{2}<0, \beta_{3}<0 \text { and } \beta_{4}<0 ;
$$

that is, increasing income increases educational demand, increasing price decreases educational demand, increasing opportunity cost decreases educational demand and increasing cohort size decreases educational demand. ${ }^{2}$ Note that within this framework nonsignificance of the opportunity cost variable would suggest rejection of an important component of the investment theory, while nonsignificance of the cohort size variable would suggest rejection of the cohort size theory. Since the income variable is a component of all theories and the price variable a component of both the consumption and investment theories, nonsignificance of these variables does not lead to such unambiguous conclusions.

Note that when specified as a rate, the dependent variable can be interpreted as the probability that a college or university-aged person will enrol in a postsecondary educational institution. Such a specification is, therefore, based in the binary choice models that pervade much of the empirical work on individual decision making in economics (see, for example, Amemiya, 1981). Since the purpose of this paper is aggregative in nature - being concerned with the determinants of the province-wide enrolment rate over time - the above specification can be reinterpreted as an aggregation of individual choices in each time period. The estimation problems associated with such an interpretation are examined in Section 4 below.

The following section briefly outlines the data used to measure each of the variables appearing in the general relationship outlined above. The results of estimating the relationship using these data are then presented and discussed in the subsequent section.

\section{DATA}

The number of full-time students in postsecondary institutions in Ontario over the 1960s and 1970s are shown in Table 1. These data show that postsecondary enrolment in the province more than tripled over the decade of the $1960 \mathrm{~s}$, but increased by less than 50 per cent over the decade of the 1970s. By 1979 almost 225,000 full-time students were attending a postsecondary educational institution in the province. This represented approximately 28.2 per cent of the population aged 20 to 24 years. $^{3}$ Of the total, almost 140,000 (or 62 per cent) were undergraduates, 70,000 (or 31 per cent) were community college students and 15,000 (or 7 per cent) were graduate students.

In recent years, university enrolment rates have declined from their mid-1970s peaks, while community college rates continue to edge upwards after the dramatic increases following the creation of the Community College System in the province in $1967 .{ }^{4}$ Overall, postsecondary enrolment rates in the province peaked in the mid-1970s and have since declined slightly. Consequently, the data used in this study encompass a period of rapid growth followed by stabilization and modest decline, and it is these data that the above theories must attempt to explain. 
TABLE 1

FULL-TIME, POST-SECONDARY ENROLMENTS IN

ONTARIO, 1961-1979

\begin{tabular}{|c|c|c|c|c|c|}
\hline Year & Undergraduate & Graduate & $\begin{array}{c}\text { Total } \\
\text { University }\end{array}$ & $\begin{array}{l}\text { Community } \\
\text { College }\end{array}$ & $\begin{array}{c}\text { Total } \\
\text { Post-Secondary }\end{array}$ \\
\hline 1961 & 33,073 & 2,903 & 35,976 & 3,959 & 39,935 \\
\hline 1962 & 36,058 & 3,328 & 39,386 & 3,990 & 43,376 \\
\hline 1963 & 40,166 & 4,201 & 44,367 & 4,743 & 49,110 \\
\hline 1964 & 45,563 & 5,424 & 50,987 & 5,718 & 56,705 \\
\hline 1965 & 52,415 & 6,859 & 59,274 & 7,397 & 66,671 \\
\hline 1966 & 61,203 & 7,727 & 68,930 & 10,267 & 79,197 \\
\hline 1967 & 69,651 & 9,782 & 79,433 & 18,511 & 97,944 \\
\hline 1968 & 81,434 & 11,498 & 92,932 & 27,004 & 119,936 \\
\hline 1969 & 95,367 & 13,458 & 108,825 & 32,723 & 141,548 \\
\hline 1970 & 106,304 & 14,811 & 121,115 & 37,483 & 158,598 \\
\hline 1971 & 118,039 & 16,380 & 134,419 & 37,981 & 172,400 \\
\hline 1972 & 118,700 & 16,495 & 135,195 & 42,367 & 177,562 \\
\hline 1973 & 122,463 & 16,280 & 138,743 & 54,606 & 193,349 \\
\hline 1974 & 130,615 & 16,516 & 147,131 & 55,875 & 203,006 \\
\hline 1975 & 137,908 & 17,650 & 155.558 & 59,640 & 215,198 \\
\hline 1976 & 143,791 & 17,151 & 160,942 & 58,919 & 219,861 \\
\hline 1977 & 142,701 & 15,661 & 158,362 & 60,994 & 219,356 \\
\hline 1978 & 138,974 & 15,417 & 154,391 & 64,499 & 218,890 \\
\hline 1979 & 139,663 & 14,952 & 154,615 & 70,213 & 224,828 \\
\hline
\end{tabular}

Sources: Statistics Canada, Historical Compendium of Education Statistics from Confederation to 1975 (Catalogue No. 81-568), and selected issues of Enrolments and Degrees (Catalogue No. 81-204) and Enrolments in Commanity Colleges (Catalogue No. 81-222).

The satisfactory measurement of the explanatory variables suggested by the theories continues to remain a challenge of empirical research. As previously inferred, the general unavailability of individual-specific data has resulted in most researchers in this subject turning to aggregate data to test the theories. This requires the use of proxy measures of the relevant theoretical constructs at the aggregate level. Moreover, since it is at this level that much of the policy debate centres, these measures tend to be chosen from widely available and respected 
data sources in the expectation (hope?) that the debate will be focussed on the issue and not on the possible measurement problems associated with each specific variable. Under these conditions, the accumulated findings of a number of different researchers in different jurisdictions represents the emerging conclusions in the discipline.

In this study, the income variable is measured as real ${ }^{5}$ personal disposable income per capita in the province. This is an appropriate measure for testing the consumption theory and acts as a proxy measure for testing the investment theory. Over the period this variable has increased from $\$ 2,292$ per person to $\$ 4,119$ per person (in $\$ 1971$ ) for an average annual growth of 3.1 per cent. However, over the last half of the decade of the 1970s (1975-79) average growth had declined to around 1.0 per cent per annum. Recall that the expected influence is positive (that is, estimated $\beta_{1}>0$ ).

Constructing an accurate measure of the average price variable is very difficult given the myriad and complexity of postsecondary programs and institutions in Ontario. Moreover, this variable reflects, in large part, provincial government policy towards postsecondary education in the province. For these reasons it was decided to proxy these influences by a measure of per student real operating grants from all levels of government to postsecondary institutions in the province. ${ }^{6}$ An increase in real operating grants per student is likely to reflect a provincial government policy to mitigate fee increases, while a decrease will almost certainly result in increased average per student fees. This variable therefore reflects a fundamental feature of postsecondary education in the province, namely, the role of provincial government policy in influencing the fee structure and hence educational demand. This variable increased from $\$ 2,900$ (in \$1971) in 1961 to a peak of slightly over $\$ 4,250$ in 1971 , but had declined to around $\$ 3,700$ (in $\$ 1971$ ) by 1979 . Consequently, this suggests that the 1960 s could be characterized as a decade of declining average prices, while the 1970 s could be characterized as a decade of slightly increasing average prices. Finally, note that because of the inverse relationship between operating grants and fees, the expected sign on the fee variable, as measured, is now positive (that is, estimated $\beta_{2}>0$ ).

The third explanatory variable, which follows from the investment theory, is a measure of the opportunity costs of postsecondary education. Following Handa and Skolnick (1975) and other authors (see above) this influence is captured by a measure of unemployment in the relevant age groups in the provincial economy. Increased unemployment rates can be expected to lower the opportunity costs of a postsecondary education and, hence, increase enrolment rates. However, numerous changes in policies towards unemployment and in the measurement of unemployment over this period have made the direct use of the unemployment rate as a measure of the opportunity cost influence problematic. For this reason, a variable showing the unemployment rate for the relevant age groups standardized (or divided) by the general unemployment rate in the province was constructed and tested in the estimated equations and generally performed better than the unemployment rate alone. Using the 20 to 24 year age group this variable declined 
TABLE 2

DETERMINANTS OF TOTAL POST-SECONDARY ENROLMENT

RATES, ONTARTO, 1961-79a

\begin{tabular}{|c|c|c|c|c|c|c|c|c|}
\hline $\begin{array}{c}\text { Theoretical } \\
\text { Variable }\end{array}$ & & $\begin{array}{c}\text { Structural } \\
\text { Change }\end{array}$ & Income & Price & $\begin{array}{c}\text { Opportumity } \\
\text { Costs }\end{array}$ & $\begin{array}{l}\text { Cohort } \\
\text { Size }\end{array}$ & & \\
\hline $\begin{array}{l}\text { Measured } \\
\text { Variable }\end{array}$ & Constant & $\begin{array}{c}\text { Dummy } \\
\text { variableb }\end{array}$ & $\begin{array}{l}\text { Real P.D.I. } \\
\text { per capita }\end{array}$ & $\begin{array}{l}\text { Real Operating } \\
\text { Grants per Stu- } \\
\text { dent }\end{array}$ & $\begin{array}{l}\text { Relative } \\
\text { Unemployment } \\
\text { Ratec }\end{array}$ & $\begin{array}{l}\text { Lagged } \\
\text { Fertility Rate }\end{array}$ & \multicolumn{2}{|c|}{$\begin{array}{l}\text { Equation } \\
\text { Statistics }\end{array}$} \\
\hline Expected Sign & & $(+)$ & $(+)$ & $(+)$ & $(+)$ & $(-)$ & $\overline{\mathrm{R}}^{2}$ & DW \\
\hline Equation \#1 & $\begin{array}{r}-18.582 \\
(3.1)\end{array}$ & $\begin{array}{l}2.916 \\
(1.7)\end{array}$ & $\begin{array}{l}7.362 \\
(9.0)\end{array}$ & $\begin{array}{l}4.027 \\
(2.8)\end{array}$ & & & 0.967 & 0.74 \\
\hline Equation \#2 & $\begin{array}{r}-26.085 \\
(4.1)\end{array}$ & $\begin{array}{l}2.243 \\
(1.4)\end{array}$ & $\begin{array}{l}6.660 \\
(8.2)\end{array}$ & $\begin{array}{l}4.212 \\
(3.3)\end{array}$ & $\begin{array}{l}6.879 \\
(2.1)\end{array}$ & & 0.973 & 1.17 \\
\hline Equation \#3 & $\begin{array}{r}-24.047 \\
(3.9)\end{array}$ & $\begin{array}{l}3.051 \\
(1.9)\end{array}$ & $\begin{array}{l}8.956 \\
(5.6)\end{array}$ & $\begin{array}{l}4.859 \\
(3.8)\end{array}$ & $\begin{array}{l}7.638 \\
(2.5)\end{array}$ & $\begin{array}{c}-4.222 \\
(1.6)\end{array}$ & 0.976 & 1.07 \\
\hline Equation $\# 4^{e}$ & $\begin{array}{c}-4.590 \\
(12.7)\end{array}$ & $\begin{array}{l}0.137 \\
(1.5)\end{array}$ & $\begin{array}{l}0.575 \\
(6.1)\end{array}$ & $\begin{array}{l}0.447 \\
(6.0)\end{array}$ & $\begin{array}{l}0.352 \\
(1.9)\end{array}$ & $\begin{array}{c}-0.259 \\
(1.7)\end{array}$ & 0.981 & 1.03 \\
\hline
\end{tabular}

Notes: a - Rates expressed as a percentage of the population aged 20 to 24 years. t-statistics in parentheses. b - Zero for 1961-66, one for 1967-79.

c - Unemployment rate of 20 to 24 year olds divided by total unemployment rate.

d - Period total fertility rate lagged 20 years.

e - Logit estimates of equation \#3 (see text for details). 
from around 1.30 in the early 1960 s to a minimum of 1.20 in 1965 and then climbed to a maximum value of approximately 1.6 in both 1973 and 1977. For 1978 and 1979 it assumed a value of 1.42. Note that, as with the fee variable, the negative relationship between unemployment and opportunity costs results in a reversal of the expected sign on this variable (that is, estimated $\beta_{3}>0$ ).

Finally, to caputre the influence of Easterlin's cohort size theory on enrolment rates, the approach outlined by Ahlburg, Crimmins and Easterlin (1981) is used in this study. Since cohort size is reflected, in part, by previous fertility rates, the period total fertility rate for Ontario lagged 20 years is included as the cohort size variable. Since increased fertility approximately 20 years previous reflects a measure of increased "competition" amongst the current postsecondary age groups, and hence a decline in the returns to such an education, it would be expected that increased fertility 20 years ago would result in decreased current enrolment rates, and vice versa. For the period of estimation (1961-79), this variable generally increases reaching a maximum value of 3.793 (children per woman) in 1979 which is the peak of the baby-boom 20 years earlier (see Statistics Canada, 1978, p. 18).

\section{RESULTS}

The results of estimating the specification outlined in the theoretical review using the data discussed above are presented in Table 2 for total postsecondary enrolment rates in Ontario for the period 1961 to 1979. Recall that, given the way that the various variables are measured, the following signs are expected on the estimated coefficients (denoted $\hat{\beta})$ :

$$
\hat{\beta}_{1}>0, \hat{\beta}_{2}>0, \hat{\beta}_{3}>0 \text { and } \hat{\beta}_{4}<0 ;
$$

that is, increased real personal disposable income per capita, real per student operating grants (implying reduced fees), unemployment rate (implying reduced opportunity costs) and reduced fertility rates are expected to result in increased enrolment rates, and vice versa. A dummy variable was also introduced to take account of the significant re-organization of the postsecondary education system in the province in 1967.

Of particular note is that all variables have the expected estimated sign and are statistically significant at conventional levels of significance. ${ }^{7}$ The consumption theory alone (equation \# 1) would appear to provide a very satisfactory explanation of enrolment rate behaviour and many researchers might be tempted to explore no further. However, the DW statistic does provide an indication of harmful serial correlation. ${ }^{8}$ In addition this study confirms the findings of Handa and Skolnick (1975) that the introduction of the opportunity cost variable (equation \# 2) not only provides a statistically significant contribution, but also improves the DW statistic (which now lies in the inconclusive range). ${ }^{9}$ Of notable 
DETERMINANTS OF COMMUNITY COLLEGE, UNDERGRADUATE AND

GRADUATE ENROTMENT RATES, ONTARTO, 1961-79a

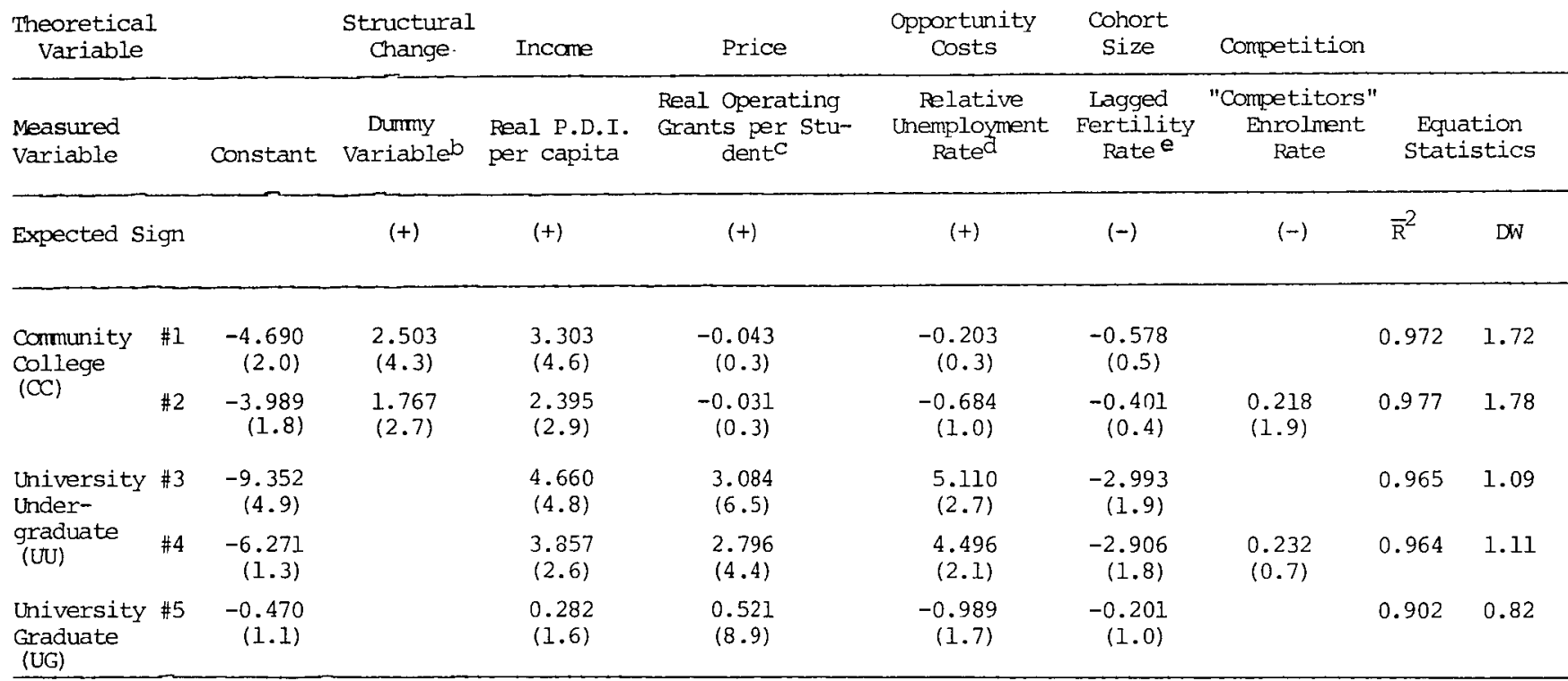

Notes: a - Rates expressed as a percentage of the population aged 20 to 24 years for CC and UU and àged 25 to 34 years for UG. t-statistics in parentheses.

b - For community colleges only (see footnote 5); zero for 1961-66, one for 1967-79.

c - Institution-specific operating grants, deflated by the consumer price index and divided by relevant student numbers.

d. - Unemployment rates of 15 to 19 years, 20 to 24 years and 25 to 34 years divided by total unemployment rate for $\mathrm{CC}, \mathrm{UU}$ and UG respectively.

e - Period total fertility rate lagged 20 years for $\mathrm{CC}$ and UU and 25 years for UG. 
interest is the effect of introducing the cohort size variable (equation \#3). This has the expected negative sign, largely leaves the signs and significance of all other variables unaffected, and marginally improves the degree of explanation $\left(\overline{\mathrm{R}}^{2}\right)$.

Being based on an aggregation of individual responses, this specification incorporates heteroscedasticity introduced by the grouping (averaging) of observations (see Johnston, 1972). Moreover, this procedure results in a dependent variable (the enrolment rate) that has a probabilistic interpretation and hence is constrained to lie between zero and 100 per cent. Under these conditions logit estimation has been suggested as the appropriate estimation technique (see, for example, Pissarides, 1982). These results (equation \#4) confirm the findings of the previous least squares (LS) results with all variables remaining of correct sign and significance. ${ }^{10}$ In this application the results confirm the not unusual finding that LS appears to provide an adequate and robust approximation to the logit specification.

To obtain some idea as to the relative importance of these determinants in each of the three different groups that comprise the full-time postsecondary student population in the province (see Table 1), separate equations were estimated for the community college, undergraduate and graduate student groups, using the equation specification and variables outlined above (appropriately modified for the different age groups). In addition, the hypothesis that community colleges and universities compete for students (at the undergraduate level) was examined by introducing the "competitors" enrolment rate into the specification. A significant negative sign would provide confirmation of this hypothesis. These results are summarized in Table 3.

An examination of these results indicates that the model is largely confirmed for (both) university enrolments but not for community college enrolments where incorrect (although nonsignificant) signs are obtained for the price and opportunity cost variables. Moreover, the university results confirm the (perhaps surprising) finding of Handa and Skolnick (1975) that the unemployment rate appears to effect undergraduate and graduate enrolment rates differently. Perhaps general unemployment rates are not a good measure of opportunity costs for higher level studies or perhaps students in those programs are more committed to completion having already incurred significant opportunity costs in the past. Also these results provide no confirmation of the "competition" hypothesis. In both cases the estimated coefficients are positive, but, either not significantly different from zero (in \#4), or not meaningful (in the "poor" community college equation \#2).

Table 4 provides elasticity estimates of the price and income variables for a selection of the equations presented in Tables 2 and 3. These variables are generally highly significant in all equations. They suggest that a one per cent increase in real disposable income in the province increases total postsecondary enrolment rates by approximately 1.3 per cent, whereas a one per cent increase in real 
TABLE 4

TNCOME AND PRICE ELASTICITIES FOR

POST-SEOONDARY ENROLMENT RATES IN

ONTARTO

\begin{tabular}{|c|c|c|c|c|}
\hline & \multicolumn{2}{|c|}{ At Mean Values } & \multicolumn{2}{|c|}{ At 1979 Values } \\
\hline & Income & Price $^{a}$ & Income & Price $^{\mathrm{a}}$ \\
\hline Total Post_Secondary (Table 1, \#3) & 1.299 & 0.824 & 1.304 & 0.638 \\
\hline Commmity college (Table 2, \#1) & 2.072 & $\ldots b^{b}$ & 1.447 & $\ldots b^{b}$ \\
\hline $\begin{array}{l}\text { University. Undergraduate } \\
\text { (Table 2, \#3) }\end{array}$ & 0.989 & 0.792 & 1.092 & 0.715 \\
\hline University Graduate (Table 3, \#5) & 0.831 & 1.859 & 1.075 & 1.965 \\
\hline
\end{tabular}

Notes: a - Measured by real operating grants per student (so a + sign is expected). b - Price variable not significant. 
operating grants per student increases total postsecondary enrolment rates by approximately 0.8 per cent. By 1979 the values were 1.3 and 0.6 per cent respectively. Community college enrolments appear to be considerably more income sensitive than university enrolments. Within the university student body, graduate enrolments appear to be far more "price" sensitive than undergraduate enrolments; that is, a one per cent decrease in real operating grants per student will reduce undergraduate enrolments by about one per cent but will reduce graduate enrolments by almost two per cent.

\section{IMPLICATIONS}

From these results it would appear that the stabilization (or even decline) in postsecondary enrolments rates in Ontario over the 1970s can be attributed to a number of factors:

1) the stabilization in the growth of real per capita personal disposable incomes in the province;

2) the reduction in real per student operating grants to postsecondary institutions, thus resulting in average fee increases; and

3) the demographic effect of increasing cohort size reducing the returns to an "investment" in postsecondary education.

Counteracting these effects has been the effect of an increase in the youth unemployment rates over the latter part of the decade, which appears to have resulted in an increase in community college and undergraduate enrolment rates.

What about the future? Is it likely that over the 1980s and beyond postsecondary enrolment rates in the province will rise or fall? The above results, while far from definitive, can be used to provide some insights into such questions. It is possible to postulate that, for example, a resumption in the growth of real per capita personal disposable income in the province would place upward pressure on postsecondary enrolment rates, whereas a relative reduction in youth unemployment rates would have the opposite effect. Continuing reductions in real per student operating grants to postsecondary institutions are likely to depress enrolment rates, especially at the graduate level. However, perhaps of more interest since it has been largely ignored to date, is the likely future effect of cohort size on postsecondary enrolment rates. The 1980 s represent the beginning of enrolments in postsecondary institutions of the children of the 1960s and 1970 s, when fertility rates and cohort sizes started to decline dramatically. Consequently, for these enrollees the expected future returns to a postsecondary education are likely to rise above the generation that preceeded them thus resulting in increasing postsecondary enrolment rates in the province. This impact is likely to continue into the 1990s, although its magnitude may be influenced by the size of the "pool" of unemployed baby-boomers that preceeded them.

A preliminary assessment of the relative magnitude of these likely effects can be ascertained by reference to the results presented in this study. The calculations presented in Table 5 provide an illustrative example of such an application. In 
TABLE 5

FUTURE POST-SECONDARY ENROLMENT RATE

IN ONTARIO: AN ILUUSTRATIVE EXAMPIE,

FOR 1990

\begin{tabular}{|c|c|c|c|c|c|}
\hline Determinants & $\begin{array}{l}1979 \\
\text { Value } \\
(1)\end{array}$ & $\begin{array}{l}\text { Assumed } 1990 \\
\text { Value } \\
\text { (2) }\end{array}$ & $\begin{array}{l}\text { Difference } \\
(3)=(2)-(1)\end{array}$ & $\begin{array}{l}\text { Estimated } \\
\text { Coefficienta } \\
\text { (4) }\end{array}$ & $\begin{array}{l}\text { Estimated Change in } \\
\text { Enrolment Rates } \\
(5)=(3) *(4)\end{array}$ \\
\hline $\begin{array}{l}\text { Real P.D.I. } \\
\text { per capita }\end{array}$ & 4.100 & 4.830 & 0.730 & 8.956 & 6.538 \\
\hline $\begin{array}{l}\text { Real Operating } \\
\text { Grants per Student }\end{array}$ & 3.696 & 3.511 & -0.185 & 4.859 & -0.899 \\
\hline $\begin{array}{l}\text { Relative Unermploy- } \\
\text { ment Rate }\end{array}$ & 1.415 & 1.415 & 0.000 & 7.638 & 0.000 \\
\hline $\begin{array}{l}\text { Lagged Fertility } \\
\text { Rate }\end{array}$ & 3.773 & 2.401 & -1.372 & -4.222 & 5.793 \\
\hline Total & & & & & 11.432 \\
\hline
\end{tabular}

Note: a - Table 2, Equation \#3. 
this example, it is assumed that per capita real income growth in the province over the 1980 s averages 1.5 per cent per annum, somewhat above the record of the latter half of the 1970s but below the record of the entire decade. Relative youth unemployment rates are assumed to remain at their 1979 level (which is a reduction of 0.15 from the 1982 value of 1.57 ). In addition, the decline in the per student real operating grants from all levels of government to postsecondary institutions in the province is assumed to be somewhat arrested with a further five per cent erosion over the 1980s compared to 13.1 per cent over the 1971-79 period. Finally, it is already known that the relevant fertility rate declines over the 1980 s - the relevant value for 1990 being the actual value of 2.401 for 1970 .

These illustrative calculations suggest that, on average, enrolment rates in postsecondary institutions in Ontario are likely to increase substantially over the $1980 \mathrm{~s}^{11}$, primarily as a result of increasing per capita incomes and decreasing cohort sizes. Offsetting such impacts may be a further erosion in real terms of operating grants to universities (thus resulting in fee increases) and, perhaps, reduced relative youth unemployment rates (which has been excluded from the above example). The sensitivity of these results to alternative assumptions can be easily explored by similar calculations. For example, a decrease in the relative youth unemployment rate by ten per cent would result in an estimated change of $-1.085(=-0.142 * 7.638)$ in postsecondary enrolment rates in Ontario. However, the one impact that is not possible to change is the cohort effect since the change in the lagged fertility rate is already known with certainty. According to these calculations this effect alone can be expected to result in an increase in postsecondary enrolment rates of approximately one fifth over the decade of the 1980s.

If correct - and there are many reasons why the estimates presented in this paper must be treated as preliminary ${ }^{12}$ - such an increase may be sufficient to completely offset the impact of declining cohort size on postsecondary enrolments over the 1980s and beyond. Projected declines of relevant cohort size of the order of 20 per cent over the 1980s and beyond may well be matched by increases in enrolment rates of a similar magnitude. ${ }^{13}$ Under these conditions the often-anticipated decline in postsecondary enrolments in Ontario and elsewhere, which reflects in large part the projection of the elementary and secondary school experience into postsecondary education, will not materialize and current public policy towards postsecondary institutions must be careful to incorporate this information.

\section{CONCLUSIONS}

Traditional economic theories of educational demand can provide a useful framework within which to understand the determinants of postsecondary enrolment rates. Previous studies have tended to be based on a single theory - the consumption theory, the investment theory or the cohort size theory - but in reality, elements of all three approaches may be relevant to an individual's decision to 
seek a postsecondary education. In the results presented in this study - for the province of Ontario, Canada over the 1960s and 1970s - elements of all three theories are shown to contribute significantly to an explanation of postsecondary full-time enrolment rates, which grew rapidly over the 1960s and then stabilized over the 1970s.

In particular, the results suggest that the observed pattern of enrolment rates over this period can be attributable to:

1) rapid growth in real per capita incomes in the province over the 1960s and early 1970s followed by a stabilization over the latter half of the 1970s;

2) increases in real per student operating grants to postsecondary institutions over the 1960s, thus enabling real average fee (or price) decreases over the decade followed by a reversal over the 1970s;

3) the demographic effect of cohort size gradually decreasing the returns to an "investment" in education over the period, but especially over the 1970s; and

4) to some degree counteracting the above trends, (relative) declines in the youth unemployment rates over the mid.1960s thus reducing the opportunity costs of and hence demand for a postsecondary education, followed by relatively high rates over the 1970 s leading to the opposite effects.

Whether or not these trends will continue into the 1980s and beyond remains an important issue in public policy. Resumption of real per capita income growth in the province could be expected to increase educational demand, while continuation of the declines in real operating grants to postsecondary institutions in the province would have the opposite impact. Continued high youth unemployment rates might be expected to maintain the demand for a postsecondary education, whereas a reduction might lead to a decline in enrolment rates. However, because of the lag in the cohort size variable, the values of this variable are known for certain for the next twenty years. Since the current generation of students are associated with the peak in fertility rates which occurred in the late 1950s, the subsequent declining rates can be expected to result in increased postsecondary enrolment rates over the 1980s and 1990s as smaller cohort sizes reduce the "competition" and hence increase the expected returns to a postsecondary education.

As a consequence, the widespread belief that the next decade or two will produce substantial declines in the enrolments of institutions of higher learning in Ontario (and in Canada) would appear to be in need of urgent re-evaluation. While smaller cohort sizes will undoubtedly reduce postsecondary enrolments (as noted in several recent studies), the effects of population aging (see Foot 1981 for greater elaboration) and possibly increasing enrolment rates over the period may well counteract these demographic trends. Under such conditions, public policy towards postsecondary institutions, especially universities ${ }^{14}$,'should not be determined on the basis of substantial anticipated enrolment declines. 


\section{FOOTNOTES}

1. A linear specification is chosen for expository convenience.

2. Note that adopting a demand-theory approach implicitly assumes an elastic supply of potential enrolees. This would appear to be a reasonable assumption in Ontario over this period.

3. The majority of full-time students come from this age group so this was used as the relevant age group. See Foot (1981) for details. The use of other age groups did not change the reported results noticeably.

4. Prior to 1967 , Community College enrolments represent students in schools of nursing, technical trade schools and related institutes.

5. Current dollar magnitudes are converted into constant (or real) dollar magnitudes by dividing by the consumer price index for each year.

6. Data for universities are from Statistics Canada, Historical Compendium of Education Statistics (Catalogue 81-568) and unpublished sources. Data for community colleges are unpublished Statistics Canada data (1960-68) and from Financial Statistics of Education (Catalogue 81-208) (1969-79). In all cases real values are obtained by dividing by the consumer price index. Note that even though operating costs are enrolmentbased there are sufficient lags in the formula so that this variable does, in fact, represent an independent measure of price.

7. Note that one-tail t-tests are appropriate and the relevant values are 1.35 and 1.77 for the 10 and 5 per cent levels respectively.

8. The relevant lower limit of 0.97 at the 5 per cent level and 0.74 at the 1 per cent level.

9. The 20 to 24 year unemployment rate dominated the unemployment rate variable of the con tiguous age groups. As previously noted, the relative unemployment rate variable performed better than the absolute unemployment rate.

10. Note that the dependent variable is now $\ln (\mathrm{ENR} /(100-\mathrm{ENR})$ where $1 \mathrm{n}$ stands for logarithm and ENR for the enrolment rate, so that the estimated coefficient and equation statistics cannot be readily compared with the least squares results.

11. The Table 5 estimate of 11.432 represents an increase over the 1979 value of approximately 40 per cent.

12. For example, there is no guarantee that the responses and structure that existed over the 1960s and 1970s which is embodied in the estimated equations will remain in force over the 1980 s.

13. Mathematically, this can be shown by noting that total enrolments (EN) can be expressed as the product of the enrolment rate (ENR) and the relevant population (POP); that is

$$
\mathrm{EN}=\mathrm{ENR} * \mathrm{POP} \text {. }
$$

Taking time derivatives and expressing these as percentage changes (denoted by a dot above the variable) results in

$$
\dot{\mathrm{EN}}=\mathrm{E} \dot{\mathrm{NR}}+\dot{\mathrm{POP}}
$$

Hence a $\dot{P O P}=-20$ can be offset by an $\dot{E N R}=+20$ which leaves no change in the level of enrolments $(\mathrm{EN}=0)$.

14. The nonexistence of graduate programs in community colleges and the lack of confirmation of the model used in this paper for community colleges implies that this conclusion may not be quite as relevant for community colleges.

\section{REFERENCES}

Ahl burg, D., Crimmins, E.M. \& Easterlin, R.A. The Outlook for Higher Education: A Cohort Size Model of Enrolment of the College Age Population, 1948-2000. Review of Public Data Use, 1981, 9(3), 211-227. 
Amemiya, T. Qualitative Response Models: A Survey.Journal of Economic Literature, 1981, $19(4), 1483-1536$.

Becker, G.A. Human Capital: A Theoretical and Empirical Analysis with Special Reference to Education. New York: Columbia University Press for the N.B.E.R., 1964.

Campbell, R. \& Siegel, B.N. The Demand for Higher Education in the United States, 1919. 1964. American Economic Review, 1967, 57(3), 482-494.

Clark, W., Devereaux, M.S. \& Zsigmond, Z. The Class of 2001. Ottawa: Statistics Canada in collaboration with the Canadian Teachers' Federation, 1979.

Crean, J.F. Expected Rates of Return and the Demand for Education: Some Empirical Evidence. Quebec: Groupe de recherche sur l'économie du secteur public, 1971.

Cyert, R.M. The Management of Universities of Constant or Decreasing Size. Public Administration Review, 1978, 38 (4), 344-349.

Easterlin, R.A. Birth and Fortune: The Impact of Numbers on Personal Welfare. New York: Basic Books, 1980.

Foot, D. A Troubled Future? University Enrolments in Canada and the Provinces in Nowlan, D.M. and Bellaire, R. (eds.), Financing Canadian Universities: For Whom and By Whom? Toronto: O.I.S.E. Press, 1981.

Foot, D. Canada's Population Outlook: Demographic Futures and Economic Challenges. Toronto: James Lorimer \& Co. for the Canadian Institute for Economic Policy, 1982.

Freeman, R. Overinvestment in College Training. Journal of Human Resources, 1975, 10(3), 287-311.

Freeman, R. The Decline in Economic Rewards to College Education. Review of Economics and Statistics, 1977, $59(1), 18-29$.

Galper, H. and Dunn, R.M. A Short-Run Demand Function for Higher Education in the United States. Journal of Political Economy, 1969, 77.(5), 765-77.7.

Handa, M.L. Towards a Rational Education Policy. Toronto: O.I.S.E. Press, 1972.

Handa, M.L. \& Skolnik, M.L. Empirical Analysis and the Demand for Education in Canada, in Ostry, S. (ed.), Canadian Higher Education in the Seventies. Ottawa: Economic Council of Canada, 1972.

Handa, M.L. and Skolnik, M.L. Unemployment, Expected Returns and the Demand for University Education in Ontario: Some Empirical Results. Higher Education, $1975,4(1), 27-43$.

Johnston, J. Econometric Methods, 2nd Edition. New York: McGraw-Hill, 1972.

Keyfitz, N. The Impending Crisis in American Graduate Schools. The Public Interest, 1978, (52), 85-97.

Mincer, J. Schooling, Experience and Earnings. New York: Columbia University Press for the N.B.E.R., 1974.

Pissarides, C.A. From School to University: The Demand for Post-Compulsory Education in Britain. Economic Journal, 1982, 92 (367), 654-667.

Science Council of Canada. University Research in Jeopardy: The Threat of Declining Enrolment. Ottawa: Science Council of Canada, 1979.

Statistics Canada. Vital Statistics, Vol. 1, Births, 1975 and 1976, Catalogue No. 84-204. Ottawa: Statistics Canada, 1978.

Statistics Canada. From the Sixties to the Eighties: A Statistical Portrait of Canadian Higher Education. Ottawa: Statistics Canada, 1979. 